\title{
IAEA Inspector's Fault in Inspecting the Natanz Nuclear Site on October 28, 2019: Judicial Mechanisms for Follow-up
}

\begin{abstract}
Vahid Bazzar*
While inspecting the Natanz Nuclear Site (Iran) on October 6, 2019, an inspector of the IAEA was found to carry suspicious materials. She was prevented from entering the site by the Iranian authorities and was shortly returned to the Agency's headquarters. Iran could not prosecute her, because of the inspector's immunity by the Agency. However, in addition to exhaustion of the dispute settlement mechanisms predicted in the Agreement on the Privileges and Immunities of the IAEA which has also provided the recourse to the ICJ, Iran may prosecute the Agency by attributing the conduct of the inspector to the Agency in the national courts of non-member States of the Agency that has not accepted the immunity of international organizations as customary international law. This article deals with the immunity of international organizations and its agents, as well as examining the Agency inspector's fault in inspecting the Natanz Nuclear Site and the Judicial Mechanisms for follow-ups.
\end{abstract}

\section{Keywords}

Natanz Nuclear Site, International Atomic Energy Agency, Islamic Republic of Iran, Inspector, Immunity, Responsibility

\section{Introduction}

On October 28, 2019, when the inspectors of the International Atomic Energy Agency (IAEA) are entering the Natanz Nuclear Site for inspecting the nuclear facilities, the detector device which is used to ascertain a range of explosives containing "nitrates"

* Legal Advisor of Center of International Law Affairs (CILA). Ph.D. (AllamehTabataba'i U.). The views reflected in this article, however, are the author's own. The author may be contacted at: vahidbazzar@gmail.com/Address: 15 Mahbobi St., Saba5 (Babolsar) Mazandaran, Islamic Republic of Iran.

All the websites cited in this article were last visited on October 25, 2020. 
alarmed on a female inspector repeatedly. She attempted to destroy the suspicious material at the toilet, but the detector device alarmed on the toilet again. Subsequent tests on the inspector's hotel and its personal belongings specifically including her handbag also confirmed previous results. Therefore, Iran informed the Agency to cancel her inspectorship. She eventually left Iran for the Agency's headquarters in Vienna without completing her mission. ${ }^{1}$

Following the adoption of the Joint Comprehensive Plan of Action (JCPOA), Iran's nuclear activities were inspected mainly under the Additional Protocol to the Safeguards Agreement. As such, about 150 people have been constantly inspecting all Iranian nuclear activities; these were even extended to unannounced activities and sites in Iran. ${ }^{2}$ JCPOA excludes the IAEA inspectors' access to Iranian military sites and activities due to national security issues. Moreover, following the specific arrangements provided in the JCPOA, inspecting Iran's nuclear activities and sites are limited to 15 years from the adoption day. ${ }^{3}$ Afterwards, the Agency's inspection must be under the Subsidiary Arrangements and the Additional Protocol to the Safeguards Agreement. ${ }^{4}$

The primary purpose of this research is to examine the legal aspects of the IAEA inspector's fault in inspecting the Natanz nuclear site and its legal follow-up strategies. This paper consists of four parts including Introduction and Conclusion. Part two will deal with the immunity of international organizations and its agents. Part three will examine the Agency inspector's fault in inspecting of the Natanz Nuclear Site and judicial mechanisms for follow-up.

1 See New Details of the Story of Preventing the Agency Inspector from Entering Natanz / Suspicious Bag of the Inspector, TASNIM News, Nov. 10, 2019, https://tn.ai/2137249 <available only in Persian>; Gharibabadi's Account of the Suspicious Action of the IAEA Inspector at the Natanz Nuclear Site, Borna News, Nov. 8, 2019, https://www.borna. news/fa/tiny/news-921236. < available only in Persian>

2 Joint Comprehensive Plan of Action (JCPOA), July 14, 2015, 9 ๆ 74-78.

3 It is adopted 90 days after the endorsement of the JCPOA by the UN Security Council. Six days after the Finalization of JCPOA (Finalization Day), it was endorsed by the Security Council Resolution 2231. See S.C. Res. 2231, U.N. Doc. S/RES/2231 (July 20, 2015), https://www.undocs.org/S/RES/2231(2015).

4 Iran acceded to the Comprehensive Safeguards Agreement in 1974 (Agreement between Iran and the Agency for the Application of Safeguards in Connection with the Treaty on the Non-Proliferation of Nuclear Weapons, IAEA Doc. INFCIRC/214 (Dec. 13, 1974) and to its Subsidiary Arrangements in 1976. According to JCPOA, Iran will provisionally apply the Additional Protocol to its Comprehensive Safeguards Agreement, proceed with its ratification until transition day. Transition day is the date 8 years after adoption day or the date on which the Director General of the Agency submits a report stating that the Agency has reached the broader conclusion that all nuclear material in Iran remains in peaceful activities. See M. Mohebi \&V. Bazzar, Joint Comprehensive Plan of Action (JCPOA): The Nature, Commitments, and Accesses 2 Legal IdeAL 48-9 (2018). <available only in Persian> 


\section{The Immunity of International Organization and Its Agents}

The immunity of international organizations was first granted in 1826 at the "Contingents of the Panama Congress" Convention, during which immunities were granted to the international agents of that Congress. Subsequently, diplomatic privileges and immunities were granted to staff of the League of Nations under Article 4(7) of the Covenant. ${ }^{5}$ Contrary to the immunity of States and their officials that is enshrined in customary international law, the immunity of international organizations and their agents has been regulated by treaties. When the immunity of international organizations and their agents is questioned before a court, one or more treaties would be related to the parties to the dispute. This is largely due to the fact that States are equal based on the principle of "sovereign equality" and the principle of "par in parem non hebet imperium"(equals do not have authority over one another), while international organizations do not have equal international legal personality. Unlike States, the international legal personality of international organizations is limited to their functions. In other words, international organizations only have the international legal personality they need to perform their functions. Accordingly, the immunity to international organizations, contrary to the immunity of States, is not strict, but only granted to carry out their functions properly (Principle of Functional Necessity). ${ }^{7}$ This fact is also reflected in most agreements and treaties that deal with the immunity of international organizations and their agents. For example, officials of the United Nations shall be immune from legal process in respect of words spoken or written and all acts performed by them in their official capacity. ${ }^{8}$

The immunity of international organizations is not reciprocal. National law is generally applied on international organizations. Therefore, the immunity that impedes the application of national law to international organizations is an exception and, in case of any doubt, it must be narrowly interpreted. ${ }^{9}$ This exceptionality, however, is not a customary law. In spite of maximal membership of States to the Convention on the Privileges and Immunities of the United Nations 1946 (162

5 H. Azadet al., Abuse of Immunities and Privileges of International Organizations; Looking for a Solution, 17 J. LegaL Res. 13 (2018).< <available only in Persian>

6 U.N. Charter art. 2(1).

7 F. Bordin, To What Immunities are International Organizations Entitled under General International Law? Thoughts on Jam v IFC and the 'default rules' of IO immunity, 72 Question OF INT'L L. 5-28 (2020).

Convention on the Privileges and Immunities of the United Nations 1946, art. V, ๆ 18(a).

9 S. Gh. Zamani, International Organizations Law 244-5 (2012). < available only in Persian> 
member States as of October 13, 2020) and numerous similar agreements on the immunity of international organizations, regarding it as international customary law is a matter of dispute. ${ }^{10}$ The immunity of agents of international organizations is also distinct from that of the State officials. Thus, these persons do not enjoy the immunity from the exercise of jurisdiction by the State of nationality. ${ }^{11}$ It means the agents of international organizations cannot exercise the immunity from their national jurisdiction over the actions they take in their organizational capacity. Since the agreements on privileges and immunities of international organizations and their agents have set out the general rules, dispute settlement authorities can precisely determine how much immunity is required for implementing the agents' functions.

In practice, the immunity of international organizations differs from that of States. Unlike immunity of States, which is observed almost completely in most cases, the immunity of international organizations is subject to different rules in national legal systems. For example, international organizations enjoy absolute immunity before Austrian courts. ${ }^{12}$ Italian courts do not respect the immunity of international organizations which carries out commercial or non-sovereign acts by natural persons. ${ }^{13}$ In some cases, this practice has ignored treaty obligations as well. For example, in INPDAI case, which was disputed the UN Food and Agriculture Organization (FAO)'s immunity from measures to lease a building, the Italian court ruled that FAO had no immunity in economic matters, ${ }^{14}$ although, in the headquarters agreement, absolute immunity from judicial jurisdiction is predicted unless expressly waived by the FAO. ${ }^{15}$

International organizations are composed of member States and the persons managing and working for them. Therefore, several issues may arise regarding the fault of their agents. There may be simultaneously "diplomatic protection" by the State of nationality and "functional protection" by the international organization. ${ }^{16}$

10 M. Wood, Do International Organizations Enjoy Immunity Under Customary International Law?, 10 INT'L OrG. L. Rev. 287-318 (2014).

11 C. Amerasinghe, Principles of the Institutional Law of International Organizations 316-7 (2015).

12 K. Schmalenbach, Austrian Courts and the Immunity of International Organizations, 10 InT'L Org. L. Rev. 457-63 (2014).

13 C. Young, The Limits of International Organization Immunity: An Argument for a Restrictive Theory of Immunity under the IOIA, 95 TEx. L. Rev. 909-11 (2017).

14 A. Reinisch, International Organizations before National Courts 131-3 (2004).

15 Agreement regarding the Headquarters of the Food and Agriculture Organization (FAO), art. VII, ๆ 16, Oct. 31, 1950, 1409 U.N.T.S. 521.

16 For details on the priority of support in cases diplomatic protection and functional protection, see H. Kiani \& S. Zamani, The Relation between Functional Protection for Staff in International Organization and Diplomatic Protection 
For example, the offenses of the UN peacekeeping forces are under the jurisdiction of the State of nationality. ${ }^{17}$ In some cases, however, this may create a complex situation. Imagine that the State of nationality of an organization agent causes the organization to injure that person by abusing the competence of the organization. In this regard, the State of nationality of the injured person which has unclean hands must provide diplomatic protection against the organization. Meanwhile, if the organization by the adoption of a decision binding the member State causes that State to injure its national which simultaneously is an organization agent, the organization which has unclean hands must provide functional protection against the State. $^{18}$

Agents of international organizations are generally divided into 'tstaff' and 'texperts. ${ }^{19}$ Apart from the staff of the international organizations that carryout the administrative affairs, experts are assigned to do specialized duties of the organizations in terms of their specialized abilities (such as IAEA inspectors). In its advisory opinion in the Mazilu case, the International Court of Justice (ICJ) has made considerable findings on the immunity of experts. In the Court's view, the basis of the privileges and immunities granted on the experts lies not in their administrative position but in the nature of their mission and the experts enjoy the immunities therein provided for during the period of their missions, including the time spent on journeys. ${ }^{20}$ Therefore, their immunity must be respected by all States including the State of nationality because the independence of such experts in the interests of the organization should be accorded. ${ }^{21}$ The Court also reiterated its findings in its advisory opinion in the Cumaraswamy case. ${ }^{22}$ It is interesting to note that international organizations can implement functional protection for their agents against the State of nationality, although diplomatic protection of the State's agent against other State of nationality has significant limitations. ${ }^{23}$ International organizations used to provide functional protection as an attraction to employ the

of Nationals, 49 PuB. L. Stud. Q. 70-3 (2019). < available only in Persian>

17 Supra note 9, at 277-8.

18 S. Zamani \& V. Bazzar, The Role of the Injured to the Injury in Responsibility International Law, 10 Comp. L. REv.188 (2019). <available only in Persian>

19 Convention on the Privileges and Immunities of the United Nations, Dec. 14, 1946, 1 U.N.T.S. 15, arts. 5-6.

20 Applicability of Article VI, §22, of the Convention on the Privileges and Immunities of the United Nations, Advisory Opinion, 1989 I.C.J. Rep. 177, 9 ฯ 47 \& 49 (Dec. 15).

21 Id. at $919,50-51$.

22 Id. at $9942-46,55-56$.

23 Draft Articles on Diplomatic Protection 2006, art. 7, U.N. GAOR, 61th Sess., Supp. No. 10, U.N. Doc. A/61/10 (Nov. 6, 2006). 
experts from their member States. ${ }^{24}$

\section{IAEA Inspector's Fault and the Judicial Mechanisms for Follow-up}

Irrespective of the general rules concerning the immunity of international organizations and their agents, the Agreement on the Privileges and Immunities of the International Atomic Energy Agency, which was ratified by the Parliament of Iran in 1972, is enforceable between Iran and the Agency. ${ }^{25}$ According to Article 7 of this Agreement, the experts performing missions for the Agency shall be accorded immunity in respect of words spoken or written or acts done by them in the performance of their official functions at every legal process.

Article 7, Section 25 of the Agreement provides the waiver of immunity: "... the Agency shall have the right and the duty to waive the immunity of any expert in any case where, in its opinion, the immunity would impede the course of justice and can be waived without prejudice to the interests of the Agency." Therefore, according to this Agreement, the only way to prosecute the inspector is where the Agency waives the expert's immunity, and unlike some other agreements concerning the immunity of international organizations, this Agreement does not exclude immunity in some torts. ${ }^{26}$ However, following the Agency Inspector's fault while inspecting the Natanz Nuclear Site, no waiver was issued by the Agency. Therefore, Iran could not appropriately investigate or prosecute her, and she left Iran shortly afterward. The Agency does not consider any administrative or disciplinary punishment for the inspector. Given the Agency's passive reaction to its inspector's fault, Iran could use the capacities enshrined in Article 8 of the Agreement.

According to Article 7, Section 26, if any State party to this Agreement considers that the immunity conferred by this Agreement is abused, consultations shall be

24 M. Abdollahi, Explaining and Developing the Rights of International Organizations' Brokers in Practice of the International Court of Justice, in The Role of the International Court of Justice in the Continuation and Development of International Law 121 (Hans van Loon \& S. De Dyckereds eds., 2010).

25 Because the IAEA is not a UN specialized agency, its privilege and immunity set forth in a separate document from the Convention on the Privileges and Immunities of the Specialized Agencies 1947.

26 E.g. Protocol on Privileges and Immunities of the European Patent Organization art. 3, ๆ 1 (b), Oct. 5, 1973, 1065 U.N.T.S 199; Annex I to Convention for the Establishment of a European Space Agency art. IV I 1(b), May 30, 1975, 14 I.L.M. 855. See A. Reinisch \& U. Weber, In the Shadow of Waite and Kennedy: The Jurisdictional Immunity of International Organizations, the Individual's Right of Access to the Courts and Administrative Tribunals as Alternative Means of Dispute Settlement, 1 INT'L ORG. L. Rev.62 (2004). 
held between that State and the Agency to determine whether any such abuse has occurred. If such consultations fail to achieve a result satisfying the State and the Agency, the question whether the immunity has been abused shall be settled by a procedure in accordance with Section $34 .^{27}$ Therefore, Iran may pursue this matter until recourse to the ICJ after consulting with the Agency. It is noteworthy that the Court does not initiate a contentious case in this regard, but rather renders an advisory opinion that, contrary to the nature of the Court's advisory opinions, is exceptionally binding on the parties to the dispute. ${ }^{28}$ Moreover, irrespective of jurisdictional issues, Iran cannot file the application against the inspector's State of nationality in the ICJ, because the inspector has committed fault while performing her organizational function. The matter cannot be prosecuted in the national courts of the State of nationality, either. However, the Agency may be held responsible for the fault committed by its agent.

Every internationally wrongful act of an international organization which constitutes the breach of an international obligation, entails the international responsibility of that organization. ${ }^{29}$ The origin or character of the breached obligation which may arise from treaties, customary international law, or general principles of law is not relevant for the creation of responsibility. ${ }^{30}$ Agency inspector' fault undoubtedly violates its obligation to conduct a legal and secure inspection under the Safeguards Agreement or other rules of the Organization toward its member States, including Iran. The conduct of an organ or agent of international organization in the performance of its functions shall be considered an act of that organization, whatever position the organ or agent holds in the organization under the rules of the organization. ${ }^{31}$

The ICJ has accepted a broad definition of the term "expert" in Reparation for Injuries Suffered in the Service of the United Nations case: "The Court understands the word "agent" in the most liberal sense, that is to say, any person who, whether a

27 The Agreement on the Privileges and Immunities of the International Atomic Energy Agency art. X, ๆ 34, July 1, 1959, 374 U.N.T.S. 148. It provides: "Unless in any case it is agreed by the parties to have recourse to another mode of settlement, all differences arising out of the interpretation or application of the present Agreement shall be referred to the International Court of Justice, in accordance with the Statute of the Court..."

28 The ICJ's advisory opinion has also been declared binding in a number of other cases, including the review of decisions by Administrative Tribunal of the International Labour Organization (ILO), the dispute between the United States of America and United Nations on Headquarters Agreement, and the Court's Opinion on the Disputes arising from the Convention on Privileges and Immunities of the Specialized Agencies of the United Nations.

29 Draft Articles on the Responsibility of International Organizations 2011, arts. 3-4, U.N. GAOR, 66th Sess., Supp. No. 10, U.N. Doc. A/CN.4/L.778 (May 30, 2011).

$30 \quad I d$. art. $10, \boldsymbol{\Phi} 1-2$.

31 Id. art. 6, $9 \uparrow 1-2$. 
paid officia1 or not, and whether permanently employed or not, has been charged by an organ of the Organization with carrying out, or helping to carry out, one of its functions in short, any person through whom it acts. ${ }^{, 32}$ The inspection of the nuclear sites of the member States implemented by selected experts is undoubtedly one of the principal tasks of the Agency. Even if it is claimed that the inspector's conduct was outside the authority granted to her (ultra vires), this would not be a cause for the lack of responsibility of the organization.

When the conduct of the organization's agent is in an official capacity and within the overall functions of that organization, the conduct of the agent shall be considered an act of that organization, even if the conduct exceeds the authority of that agent. ${ }^{33}$ Since the Agency inspector's fault occurred while she was in the official capacity implementing her organizational functions, the Agency's internationally wrongful act has been established. ${ }^{34}$ This conclusion has legal implications, including the continued duty of the Agency to perform the obligation breached, to offer appropriate assurances and guarantees of non-repetition, and to make full reparation. $^{35}$

Also, the lack of material damages as a result of the timely reaction of the Iranian security forces cannot, preclude the Agency's responsibility and reparation for injuries. First, the injury is not an element of an internationally wrongful act of an international organization. An internationally wrongful act of an international organization is created when conduct consisting of an action or omission is attributable to that organization under international law and constitutes a breach of an international obligation of that organization. The obligation to reparation also arises automatically after the internationally wrongful act is committee. ${ }^{36}$ Injury includes any damage, whether material or moral, ${ }^{37}$ and the lack of material damage cannot be considered the lack of injury.

Since the conduct-breach of IAEA's international obligation-is attributable to the Agency, Iran can invoke the Agency's international responsibility. There are two requirements in this course. One is that the "Notice of Claim" should be delivered to the responsible international organization by the injured State. In this regard,

Supra note 29, art. 8.

34 The attribution of the conduct of the Agency's inspector to the Agency will result in the Agency's international responsibility not being lifted even if the immunity of the inspector is waived by Agency because the Agency is responsible for all actions taken by its agents in their official capacity.

$36 \quad$ Id. $₫ 4$.

37 Id. art. 31, - 2. 
the injured State may specify in particular which form reparation should take. ${ }^{38}$ The other is the "admissibility" of claims which is connected to "nationality" and "exhaustion of local remedies." local remedies shall not be complied in this case, because these requirements are applicable only while a State is exercising diplomatic protection for its nationals. ${ }^{40}$

Also, the failure of Iran to take serious reaction after finding the inspector's fault and release of the inspector shortly afterward could not be considered as a loss of its right to invoke the Agency's responsibility. Iran's responses to this event including the submission of a related report concerning the inspector's fault to the Agency and the removal of her name from the list of inspectors selected to inspect Iranian nuclear sites prevent claims of waiver or acquiesce in this case. As for the reparation, in this case, restitution or compensation is not appropriate because Iran has no material damage. Rather, acknowledgment of the breach, expression of regret, or formal apology by the Agency, could be appropriate ways to repair.

The key question is in which court the international responsibility of the IAEA can be pursued? A preliminary point to prosecute the Agency is to decide whether an international organization has an international legal personality independent from its member States and whether it is responsible for its actions which are performed through their organs and agents. The ICJ, in its advisory opinion of Reparation for injuries suffered in the service of the United Nations case, maintained that an international organization could be involved in an international dispute. ${ }^{41}$ In addition to the possibility of pursuing the matter in the ICJ under Article 10, Section 34 of the Agreement on the Privileges and Immunities of the International Atomic Energy Agency, resort to national courts can also be a good option.

There are some limitations, however, that must be considered. First, the national courts of the member States cannot be used to prosecute the Agency, because member States certainly have a treaty obligation to observe the Agency's immunity. Thus, the courts of member States which their actions are attributed to the State ${ }^{42}$ are bound to observe the State's international obligations on the Agency's immunity.

38 The responsible international organization is not bound to conform to those specifications. See supra note 29 , art. 44, ๆ 2.

39 Exhaustion of local remedies identified in the ICJ's judgments is a well-established customary international law. Iraly Interhandel Case (Switz. v. U.S.), 1959 I.C.J. Rep. 6 (Mar. 21). See also Ambatielos (Greece v. U.K.), Judgment, 1953 I.C.J. Rep. 10 (May 19); Elettronica Sicula S. P.A. (ELSI) (U.S. v. Iraly), Judgment, 1989 I.C.J. Rep. 15, qฯ 49-63 (July 20); Ahmadou Sadio Diallo (Guinea v. Dem. Rep. Congo), Judgment, 2007, I.C.J. Rep. 582, ๆף 34-48 (May 24).

40 M. Mohebi \& V. Bazzar, Concept of Invocation to International Responsibility with Emphasis on the Draft Articles of International Law Commission 2001, 48 PuB. L. STud. Q. 208 (2018).

41 Reparation of Injuries Suffered in Service of the U.N., Advisory Opinion, 1949 I.C.J. Rep. 174, 185 (Apr. 11).

42 Draft Articles on Responsibility of States for Internationally Wrongful Acts 2001, art. 4. 
However, non-member States are not required to observe this immunity. Contrary to the immunity of States, the immunity of international organizations is still disputed if not considered as international customary law. When a national court of a non-member State of international organization decides on the immunity of that organization under customary international law, such immunity is not often recognized. ${ }^{43}$ For example, in International Tin Council case, the New York Court rejected the immunity of the International Tin Council. ${ }^{44}$ In this case, the New York Court found no reason that the immunities of the International Tin Council in the territory of the host State (UK) were extraterritorially expanded and adjudicated as such. ${ }^{45}$ The US court, in International Association of Machinists case, did not grant any customary immunity to the Organization of the Petroleum Exporting Countries (OPEC), either. It specifies that the Foreign State Immunity Act (FSIA) 1976 does not apply to OPEC because the US is not a member State. Also, the International Organizations Immunities Act (IOIA) 1946 does not apply to OPEC because this Act applies only to the international organization of which the US is a member. ${ }^{46}$ Therefore, when resorting to the national courts of the Agency's non-member States, it is important to choose States that have not accepted the immunity of international organizations as customary international law.

To overcome a possible claim on the Agency's immunity in the national courts, it can be said that there is no alternative for resolving the dispute with the Agency including an internal mechanism. One of the most famous examples concerning these mechanisms is the European Court of Justice within the European Union. There is a discernible trend in recent immunity decisions concerning international organizations to consider the availability of alternative mode of settlement. ${ }^{47}$ To overcome the immunity of the Agency, widespread environmental catastrophes and violations of the fundamental human rights of the Iranian people can be reiterated, including the right to life and the right to health. Moreover, the fatal consequences of the Chernobyl and Fukushima nuclear disasters can be cited as similar examples. ${ }^{48}$ In the Jurisdictional Immunity of State case, the ICJ ruled that the immunity of State

43 Reinisch, supra note 12, at 153.

44 International Tin Council v. Amalgamet Inc., 524 NYS 2d 971(1988).

45 Id.

46 International Ass'n of Machinists and Aerospace Workers v. OPEC, 477 F. Supp. 553 (CD Cal. 1979).

47 Supra note 24 , at 72.

48 The possibility of disasters like the Chernobyl is very low, while the Fukushima accident in Japan, which has high nuclear safety technology, again raised the issue of the importance of nuclear safety and previous concerns. See S. Hojjat, Interaction and Contrast of International Environmental Law and International Nuclear Energy Law in Nuclear Accident in Fukushima Power Plant, 12 Stud. InT'L Rel. J. 179 (2019). 
from national jurisdiction is absolute and this immunity is observed even in the case of violations of fundamental human rights. ${ }^{49}$ The same conclusion can be applied to international organizations. There are also examples of the judgments of national courts and domestic laws that confirm such a conclusion. ${ }^{50}$

Another point of contention is the qualification of immunity of agents of the international organization that some national courts maintain. The courts of Italy, the Netherlands, and France rendered the decisions that only those disputes concerning qualified staff, permanently employed by international organization, should fall outside the jurisdiction of the national courts. ${ }^{51}$ To overcome the immunity of the Agency in national courts, the lack of the immunity of international organizations cannot be invoked on jure gestionis, because the Agency inspector was acting with the principal function of the Agency in inspecting Iran's nuclear sites.

The next question is whether granting immunity to the Agency by the national court is a violation of the right of access to the court? If Iran's claim against the Agency is raised in the national court of a European State, can the court's judgment confirming the immunity of the Agency be considered, for example, a violation of the right of access to the court in accordance with Article 6 of the Convention for the Protection of Human Rights and Fundamental Freedoms 1950? The answer is negative. The obligation of the State to respect the immunity of international organization does not violate its obligation to respect the right of access to the court. The European Court of Human Rights (ECHR) has affirmed this conclusion in $\mathrm{Al}$ Adsani, Waite and Kennedy, and Beer and Regan cases. ${ }^{52}$ The ECHR specifies in AlAdsani case that the actions of States concerning well-established rules of public international law on immunity cannot principally consider the inappropriate restriction on the right of access to the court. ${ }^{53}$ By contrast, some agreements on the privileges and immunities of international organizations and some judgments of courts have accepted that in cases where the granting of immunity prevents the

49 Jurisdictional Immunities of the State (F.R.G. v. Italy; Greece Intervening), 2012 I.C.J. Rep. 99, 91 (Feb. 3).

50 State Immunity Act of Canada 1985, $\mathbf{\uparrow}$ 4-6; Justice for Victims of Terrorism Act of Canada 2012, S.C. 2012, c. 1, s. 2; Foreign State Immunity Act 1976 (FSIA) and its amendments; Iran Threat Reduction and Syria Human Rights Act of United States (ITRSHRA) 2012, 126 S.T.A.T. 1214.

51 E. Gaillard \& I. Pingel-Lenuzza, International Organizations and Immunity from Jurisdiction: To Restrict or to Bypass, 51 INT'L \& COMP. L. Q. 9 (2002).

52 Al-Adsani v United Kingdom, Merits, App No 35763/97, ECHR 2001-XI; Waite and Kennedy v Germany, Merits, App No 26083/94, ECHR 1999-I; Beer and Regan v Germany, Merits, App No 28934/95, [1999] ECHR 6. See E. Brabandere, Immunity of International Organizations in Post-conflict International Administrations, 7 INT'L ORG. L. Rev. 90 (2010).

53 Al-Adsani v United Kingdom, Merits, App No 35763/97, ECHR 2001-XI, ๆ 56. 
access to the court, the organization is obliged to waive the immunity. ${ }^{54}$

\section{Conclusion}

The immunity granted to international organizations and their agents is primarily intended to enable these organizations to properly perform their functions. The IAEA inspector's conduct to carry suspicious materials on entry into the Natanz Nuclear Site on October 28, 2019 is undeniably a fault. Given the Agency's failure to waive its immunity, it is impossible to carry out a judicial action against its agent. The Agency's failure to waive the immunity of the inspector does not create international responsibility for the Agency. According to Article 7, Section 25 of the Agreement on the Privileges and Immunities of the International Atomic Energy Agency, the Agency has the right to waive the immunity of its inspector based on its discretion. However, Iran can pursue this issue by prosecuting the Agency since the conduct of the agent shall be considered an act of that organization when the conduct of the agent is in an official capacity and within the overall functions of that organization, even if the conduct exceeds the authority of that agent (ultra vires). The fault of the inspector, which is a breach of the international obligation of the Agency, can create the international responsibility of the Agency. The first conceivable action against the Agency is to resort to the mechanism provided in the Agreement on the Privileges and Immunities of the International Atomic Energy Agency. Under its Article 8, Section 26, Iran, which claims abuse of the immunities granted under the Agreement, can consult with the Agency and if such consultations fail to achieve a result satisfactory to the State and the Agency, it may request the ICJ to deliver an advisory opinion through the General Assembly or the Security Council on whether any such abuse has occurred. This opinion, if rendered, is binding on Iran and the Agency.

A more appropriate way to prosecute the Agency is to resort to the national

54 E.g. Annex I to the Convention for the establishment of a European Space Agency art. IV, 1 1(a). It provides: "The Council has the duty to waive this immunity in all cases where reliance upon it would impede the course of justice and it can be waived without prejudicing the interests of the Agency." Also, the International Labor Organization's Administrative Tribunal in Rubio case specifies that refusing to accept an application would result in a breach of the right of access to the court because the applicant cannot submit its claim in the national courts that would be contrary to the Universal Declaration of Human Rights (1948) and the American Convention on Human Rights (1969). Thus, the court cannot declare without jurisdiction. See Rubio v. Universal Postal Union, Case No. 1644, Judgment, 1997 Int'l Lab. Org. Admin. Trib. 12 (July 10). 
courts of Agency's non-member States that do not consider the immunity of international organizations as customary international law. Although the immunity of international organizations as customary international law is disputed, Iran could raise this case by focusing on a lack of alternative mode of settlement, the widespread environmental catastrophes, and violations of the fundamental human rights of the Iranian people. Even if Iran's claim is rejected because of accepting the immunity of the Agency and its agent, the Agency is still responsible for its inspector's fault. In its advisory opinion in the Cumaraswamy case, the ICJ specifies that the question of immunity from legal process is distinct from the issue of compensation for any damages incurred as a result of acts performed by the international organization or by its agents acting in their officia1 capacity. ${ }^{55}$

Received: August 15, 2020

Modified: October 30, 2020

Accepted: November 15, 2020

55 Difference Relating to Immunity from Legal Process of a Special Rapporteur of the Commission on Human Rights, Advisory Opinion, 1999 I.C.J. Rep. 62, 66 (Apr. 29). 
